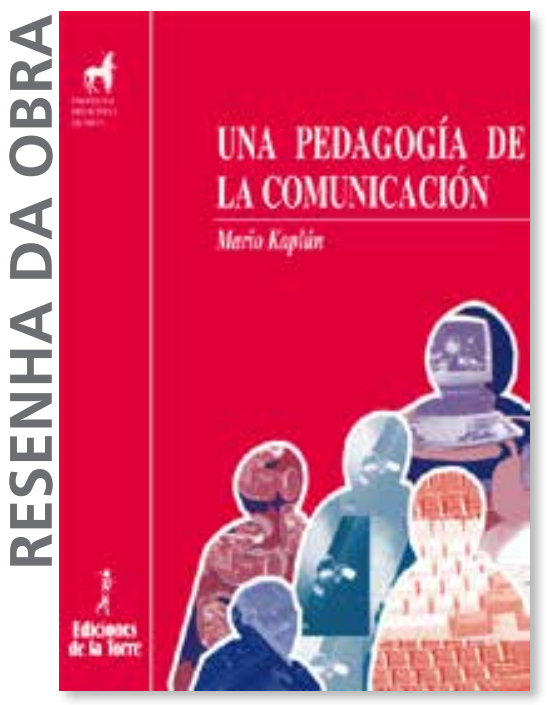

KAPLÚN, Mario. Una pedagogía de la comunicación. Madrid: Ediciones de La Torre, 1998. 252 p.

\title{
Comunicação e Educação: caminhos do saber compartilhado
}

Observação da especialista espanhola em novas mídias digitais Tíscar Lara (2008) me chamou atenção. Ela fez circular na internet mensagem na qual dizia que a obra de Mario Kaplún Una Pedagogía de la Comunicación é indispensável, embora tenha sido escrita antes da chegada da internet.

Kaplún começa seu livro sugerindo que há três modelos distintos de fazer educação. Cada modelo destaca: (1) conteúdos, (2) efeitos, ou (3) processos.

A pedagogia dos conteúdos entende que o saber pode ser empacotado em unidades para entrega aos alunos. O que importa é produzir parcelas de conhecimento que possam ser transferidas da fonte para o destino desejado. Paulo Freire deu a tal modelo o nome de educação bancária.

Segundo Kaplún (1998, p. 24):

La educación bancaria dicta ideas, no hay intercambio de ideas. No debate o discute temas. Trabaja sobre el educando. Le impone una orden que él no comparte, a la cual sólo se acomoda. No le ofrece medios para pensar auténticamente, porque al recibir las fórmulas dadas, simplemente las guarda. No las incorpora, porque la incorporación es el resultado de 
la búsqueda, de algo que exige de parte de quien lo intenta, un esfuerzo de re-creación, de invención.

A educação bancária pode acontecer em qualquer ambiente, na sala de aula ou em redes de educação a distância. Pode acontecer em situações pobres em termos de meios de informação, assim como em meios muito ricos em tecnologia.

Em tal modelo, o aluno é apenas receptor do que o sistema lhe destina. Não tem voz no processo. Não dialoga, nem com os mestres, nem com o conteúdo.

Em quadro resumo desse primeiro modelo, Kaplún assim descreve os dois atores da educação:

- o comunicador emite, fala, escolhe o conteúdo das mensagens, é sempre o que sabe;

- $\quad$ o receptor recebe, escuta, consome informação, e nada sabe.

Consideremos duas metáforas básicas sobre educação, a do auditório e a do laboratório. A primeira não muda com novos meios, porque um auditório com as mais avançadas tecnologias digitais continua a ser um auditório. A segunda, pouco comum, é encontrada nas situações em que os alunos trabalham ativamente os conteúdos do saber.

Já o segundo modelo Kaplún descreve como situação na qual o pressuposto dos planejadores é o de que compete à educação mudar comportamentos ou modelar condutas. Essa descrição lembra o Instructional System Design (ISD).

Richard Coyne faz crítica ao ISD coincidente à análise de Kaplún:

No âmbito de tendências conservadoras, design é uma intervenção, uma manipulação. É converter uma situação indesejada numa situação desejada. Ele [o design] pressupõe nossa habilidade em explicitar necessidades, desejos e intenções. [...] A visão conservadora presume que os designers podem controlar, e estão no controle daquilo que produzem. Esse controle é efetivado na atividade de design por meio do método. Uma sequência de passos nos leva da situação indesejada para a situação desejada (COYNE, 1997, p. 10-11)

Coyne destaca as linhas gerais da teoria de sistemas. No âmbito de tal teoria, especialistas criam soluções para resolver problemas. E a natureza dos problemas é determinada pelos mesmos especialistas. Supostos beneficiados pela solução proposta são ignorados. O que vale é a capacidade do especialista em identificar problemas e propor solução. Tudo ocorre como se os problemas fossem situações inteiramente neutras. Essa análise já foi feita por Donald Schon (1979), mostrando que a identificação de problemas psicos- 
sociais não é uma decisão técnica, mas escolha que depende de metáforas tácitas sobre a realidade social. A escolha é sempre ideológica. Por isso, ele faz o seguinte alerta:

Precisamos nos tornar conscientes dos caminhos que utilizamos para estabelecer problemas sociais. Precisamos refletir sobre os processos de colocação do problema que geralmente são tácitos, pois assim poderemos selecionar conscientemente e criticar as molduras que dão forma às nossas respostas (SCHON, 1979, p. 269).

Kaplún situa o movimento de uma educação que se propõe como instrumento para a mudança de comportamento, principalmente, em iniciativas que deram grande destaque à definição de objetivos educacionais na década de 1960.

Para o autor, o segundo modelo tem, entre outras, as seguintes características:

- a decisão sobre os conhecimentos que entrarão na trama educacional é do especialista ou programador;

- o planejamento da educação é concebido como engenharia comportamental;

- $\quad$ há uma aparência de participação, porém os educandos podem apenas tomar iniciativas dentro do roteiro cuidadosamente planejado;

- a proposta é individualista, isolando as pessoas e criando dificuldade para aprendizagens colaborativas;

- a recompensa individual presente no modelo reforça valores utilitários e mercantis;

- o método não favorece desenvolvimento do raciocínio, e sim a obtenção de resultados;

- o método também não promove a curiosidade, o interesse pelo saber, a capacidade de estabelecer relações entre saberes.

O segundo modelo é hegemônico entre especialistas que utilizam as novas mídias para a educação. E muitas das limitações do modelo não são identificadas. Por essa razão, dei destaque aqui às observações de Coyne sobre abordagens sistemáticas no design.

Já o terceiro modelo, inspirado em Paulo Freire, enfatiza o processo, o engajamento dos alunos na elaboração compartilhada de saberes. Não se trata de uma educação para informar, para transmitir conteúdos, nem de uma educação que tem por meta modificar comportamentos. Como lembra Paulo Freire:

- a relação educacional não é unidirecional: educador > educando;

- há sempre uma relação de dualidade: educador $<>$ educando; 
- $\quad$ ninguém se educa isoladamente. Todos se educam mutuamente;

- $\quad$ a educação é sempre um processo participativo de elaboração do saber.

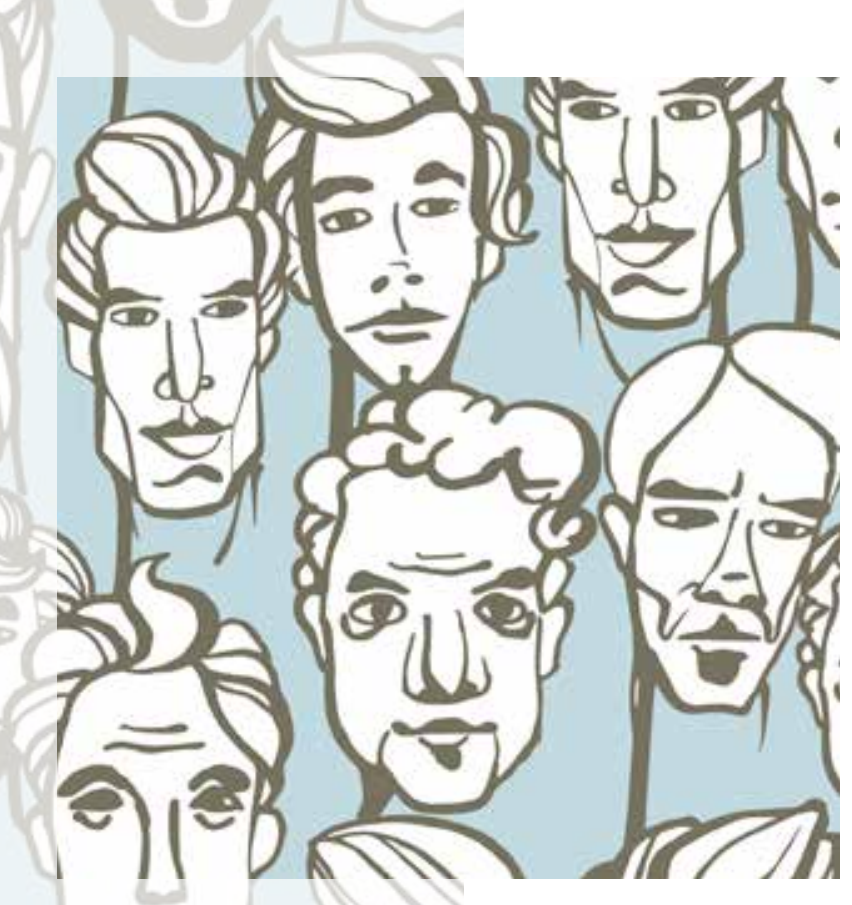

No âmbito desse modelo, a educação é sempre transformadora. É sempre uma construção social de saberes. Nela os educadores e educandos transformam-se mutuamente.

Kaplún observa que uma educação voltada para o processo não significa ignorar a necessidade de trabaIhar com informações existentes.

Não há "química pura" de qualquer dos três modelos educacionais examinados. O que há são ênfases. E essas ênfases são determinantes no uso de novas mídias. Cabe reparar que novas mídias per se não favorecem nenhum dos modelos apresentados pelo autor. O que caracteriza os modelos são as escolhas dos educadores.

Kaplún mostra que informação e comunicação são vistas como equivalentes. Nota que, inicialmente, falava-se em sistemas de informação ou meios de massa (mass media). Mas com o tempo, informação e comunicação começaram a ser utilizadas de maneira intercambiável. Por essa razão, é preciso dedicar alguma atenção ao significado desses termos.

A palavra informação entrou no cenário para descrever a intensa circulação de dados que se avoluma com as facilidades de transmissão proporcionadas pelos meios digitais. E essa transmissão acabou se convertendo em uma metáfora poderosa em várias áreas do saber humano.

Três físicos (BARATO; HARTICH; SEIFER, 2014), por exemplo, estudam trocas entre células e ambiente que as cerca a partir do modelo de processamento de informação sugerido por Shannon. E, ao explicar a troca de proteínas no nível celular, esses pesquisadores usam com certa liberdade a palavra aprendizagem para descrever resultados da incorporação de informações por parte de um organismo unicelular.

Convém fazer um registro sobre relações entre educação, informação e conhecimento. O cientista Alan Kay (1995) manifesta receio de que aconteça grande consumo de informação, cujo sentido os consumidores desconhecem, sem que haja elaboração de conhecimento. 
Informação é termo que designa transmissão de símbolos, troca de proteínas no nível celular, determinação de características físicas de um organismo presentes no seu DNA etc. Em todos os casos a ideia predominante é a de transmissão de conteúdos.

A mesma ideia de transmissão é utilizada no âmbito das novas mídias. Kaplún entende que é preciso recuperar o significado original de comunicação. Comunicar não é transmitir. Comunicar é colocar em comum, compartilhar. Ele diz:

- Comunicación es el PROCESO por el cual un individuo entra en cooperación mental con otro hasta que ambos alcanzan una conciencia común.

- Información, por el contrario, es cualquier transmisión unilateral de mensajes de un emisor a un receptor (KAPLUN, 1998, p. 63).

O autor acentua que a distinção entre informação e comunicação não é apenas um cuidado de precisão linguística. O que está em jogo, no caso, é um entendimento que pode resultar em propostas educacionais completamente opostas. Quando informação e comunicação são usadas como termos equivalentes, há tendência para se praticar uma educação autoritária, que ignora a atividade interpretativa do aluno e desconhece a necessidade de atos de cooperação para se construir saberes.

Em educação, presencial ou a distância, é importante considerar as observações de Kaplún. O que ele sugere aparece em observação que convém reproduzir aqui:

La verdadera comunicación [...] no está dada por un emisor que habla y un receptor que escucha, sino por dos o más seres o comunidades humanas que intercambian y comparten experiencias, conocimientos, sentimientos (aunque sea a distancia a través de medios artificiales). Es a través de ese proceso de intercambio como los seres humanos establecen relaciones entre sí y pasan de la existencia individual aislada a la existencia social comunitaria (KAPLUN, 1998, p. 64).

O autor escreveu Una Pedagogía de la Comunicación com base em experiências de apoio a atividades de educação popular. Kaplún trabalha com um conceito de educação bastante amplo. As experiências de educação popular que ilustram utilização de meios abrangem atividades formais e informais: produção de jornais de comunidades camponesas ou de periferias urbanas, produção de vídeos comunitários, operação de rádios populares, produção teatral, redação de material para campanhas de saúde, produção de material didático. 


\begin{abstract}
O autor tematiza algumas questões práticas de comunicação e as situa em casos concretos, abordando conceitos importantes de comunicação, examinando êxitos, mostrando fracassos. Em todos os casos, parte das exigências de modelo educacional que enfatiza processo.

Merece destaque em suas narrativas a questão da participação. Ao examinar jornais, por exemplo, ele lembra que é preciso elaborar textos que reflitam interesses da população, que nasçam do cotidiano das pessoas. A decisão do que publicar não é um ato isolado de jornalistas, e sim uma decisão que nasce de conversas entre profissionais de comunicação e os leitores. Nesse sentido, Kaplún diz que o fazer dos profissionais deve refletir uma empatia entre eles e a comunidade. O que se acentua como ponto de partida não é o conteúdo, porém os atores da comunicação.
\end{abstract}

São examinados alguns aspectos técnicos que devem merecer atenção dos profissionais. Um desses aspectos é a validade aparente de peças de informação. Muitas vezes, especialistas se encantam com certas formas ou modelos que supostamente podem facilitar a comunicação. Em um dos casos examinados, Kaplún se refere a um material impresso cuja forma deveria facilitar a interação dos leitores com o conteúdo apresentado. Os autores ficaram entusiasmados com a utilização de histórias em quadrinhos para tal fim. O resultado foi um grande fracasso.

A mensagem repassada no formato criativo de histórias em quadrinhos não foi bem-aceita. O púbico-alvo, adultos de uma comunidade rural, via naquele formato uma mensagem para crianças. Essa é uma situação clara em que a validade aparente pode criar obstáculos em processos de comunicação. No nível de detalhes, coisas parecidas podem acontecer com o vocabulário empregado, com as ilustrações, com os gráficos. Kaplún examina todos esses aspectos em muitos outros casos.

Os casos contados pelo autor e as respectivas referências em termos de cuidados de produção, linguagem, qualidade dos materiais produzidos etc. funcionam como guia para pessoas interessadas em articular concretamente pedagogia com comunicação.

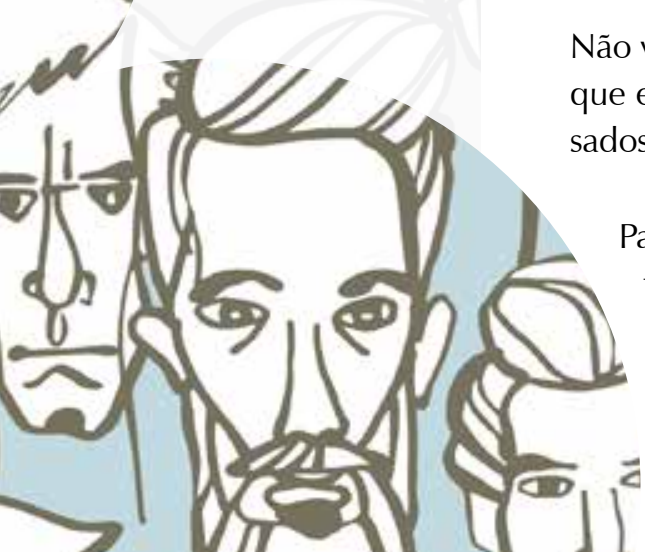

Não vou examinar com mais profundidade essa parte do livro, pois entendo que ela é um material de estudo que deve ser lido com vagar pelos interessados. Detalhes técnicos, no caso, não cabem em uma resenha.

Para mostrar articulação entre pedagogia e comunicação em projetos formais de educação, o autor recorre à história de Celestin Freinet, 
criador de um projeto educacional que pode inspirar usos da mídia no âmbito escolar.

Freinet era professor de uma escola primária no interior da França. Por volta de 1924, ele se interessou pelos meios de comunicação. Buscou informação em congressos da Escola Nova e ficou decepcionado. As propostas de uso de novas mídias eram impraticáveis em escolas pobres como a sua. Mas não desistiu. Continuou a investigar meios que poderiam ser utilizados em seu ofício de mestre-escola. E acabou encontrando uma solução. Comprou, com recursos próprios, uma pequena gráfica que poderia ser operada por ele e pelas crianças.

Com a gráfica na escola, Freinet desafiou seus alunos a produzir um jornal que deveria despertar interesse de toda a cidade. Não se tratava de um jornalzinho de estudantes. O periódico produzido pelos alunos era resultado de um processo de comunicação que envolvia não só estudantes e professor, mas também toda a cidade. Os alunos escreviam para serem lidos. Seus textos não eram tarefas escolares. Eram artigos que deveriam merecer atenção de leitores dentro e fora do espaço escolar.

A sala de aula perdeu características de auditório. Converteu-se em laboratório. Passou a ser um espaço de redação e uma gráfica. Ali, os alunos estudavam, organizavam informações, redigiam, ilustravam textos e paginavam o jornal. As informações vinham de várias fontes: de livros de estudos, de revistas, de correspondências, de entrevistas com moradores da cidade.

A produção do jornal, na escola de Freinet, era uma tarefa coletiva. Estabelecia-se, de fato, comunicação, um compartilhar de saberes intra e extra-escola. Na medida em que a experiência de Freinet tornou-se conhecida, outros educadores começaram a seguir seus passos. E o ingresso desses educadores em cena acrescentou mais uma oportunidade comunicativa: alunos de diferentes escolas começaram a desenvolver textos para troca de informações sobre suas cidades. Assim, por exemplo, alunos de Freinet recebiam informação de colegas de uma localidade cuja economia era baseada em pesca marítima. As trocas de informação entre alunos das duas escolas resultavam em matérias interessantes para os leitores. Isso concretizava uma aprendizagem de ciências sociais que nenhum livro poderia proporcionar. 


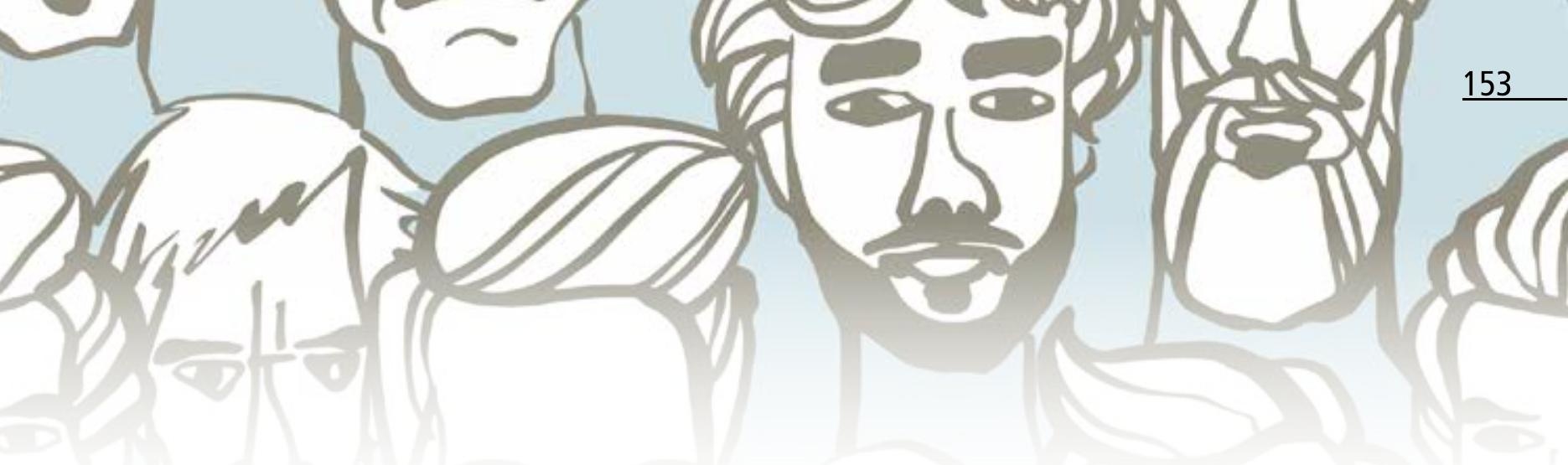

Na escola de Freinet, construía-se um saber coletivo ao qual o educador francês dava o nome de produto social. Isso é muito diferente do que se consegue com os modelos exógenos analisados por Kaplún. Havia, ali, situações em que as informações eram trabalhadas intensamente, transformadas em matérias de interesse de uma comunidade.

A experiência de Freinet é iluminadora para quem queira associar comunicação e educação. Kaplún observa que ela poderia ser reproduzida com apoio das novas mídias. Esse é um desafio que vale a pena ser proposto para alunos e professores que podem utilizar a web na produção de informações de interesse coletivo.

O autor entende que a pedagogia da comunicação vale para todas as modalidades de ensino-aprendizagem. Em seus exemplos, ele dá destaque a projetos aos quais deu apoio no campo da educação popular. A maior parte desses projetos não era escolar. Eram experiências de educação aberta vinculada à produção de periódicos, vídeos, programas de rádio, peças de teatro. Mas Kaplún não deixa de fazer referência à Educação a Distância.

Em várias partes do livro, há referências a uma educação a distância muito vinculada ao modelo que enfatiza conteúdos ou ao modelo que enfatiza mudanças comportamentais. Além disso, o autor critica o individualismo que predomina em muitos programas de EAD.

Registro, aqui, uma das críticas de Kaplún (1998, p. 216):

La modalidad de enseñanza a distancia que ha predominado hasta el presente, basada en estudiantes solitarios y aislados, genera, por su carencia de instancias de participación y su extrema pobreza en flujos comunicacionales, la situación pedagógicamente menos propicia para la recreación e interiorización del conocimiento. Significativamente, tras reiterados fracasos de este método exclusivamente individual, aun los sistemas clásicos de educación a distancia se han visto obligados a revisarse e implantar al menos, como parte obligada de sus servicios, algunos encuentros presenciales periódicos.

Essa apreciação crítica de Kaplún contrapõe-se ao pensamento hegemônico. EAD, geralmente, é vista como exemplo de educação que integra de 
maneira exemplar os recursos tecnológicos. O que se entende como exemplar, porém, é resultado de visões instrumentalistas. Muitas vezes, educação a distância e tecnologia educacional são usadas como termos intercambiáveis. Essa equiparação ignora entendimentos de comunicação como ato de compartilhar saberes.

Convém examinar projetos de Educação a Distância considerando as ênfases correspondentes aos modelos de educação para os quais Kaplún nos chama atenção na primeira parte de seu livro. Convém também considerar o significado original de comunicação na direção proposta pelo autor. É possível fazer educação a distância em uma direção transformadora, que enfatiza o processo em vez de conteúdos ou objetivos operacionais. É possível também estabelecer condições para que a aprendizagem em redes eletrônicas ocorra de modo cooperativo.

Nos anos de 1990, Kaplún já previa crescimento expressivo da Educação a Distância. Ele observa que isso ocorreria porque os meios de circulação de informações aumentariam muito. E essa previsão se cumpriu. Por outro lado, ele continua a chamar atenção para o acento individualista em tal modalidade de ensino, observando que crescia a tendência de enfatizar a interação entre o estudante e as fontes de informação, inclusive, com mecanismos que dispensariam professores e tutores.

O processo de comunicação ocorre em várias instâncias. Kaplún mostra que podemos nos comunicar por meio de manipulação de imagens, música, por meio de gestos. Mas no final de sua obra, ele acentua a instância comunicativa que acontece por meio da palavra. Para reforçar esse ponto de vista, recorre a Bruner e a Vygostsky.

Para Bruner, o educando interioriza a linguagem como instrumento cognoscitivo que facilita a elaboração de conceitos. Essa proeza, porém, não é um ato individual. Ela é, conforme Vygotsky, resultado de um discurso estabelecido por meio de intercâmbios de sujeitos que experimentam e compartilham símbolos elaborados culturalmente. Vale, uma vez mais, recorrer ao próprio autor:

El lenguaje, materia prima para la construcción del pensamiento e instrumento esencial del desarrollo intelectual, se adquiere, pues, en la comunicación, en ese constante intercambio entre las personas que hace posible ejercitarlo y de ese modo apropiárselo.

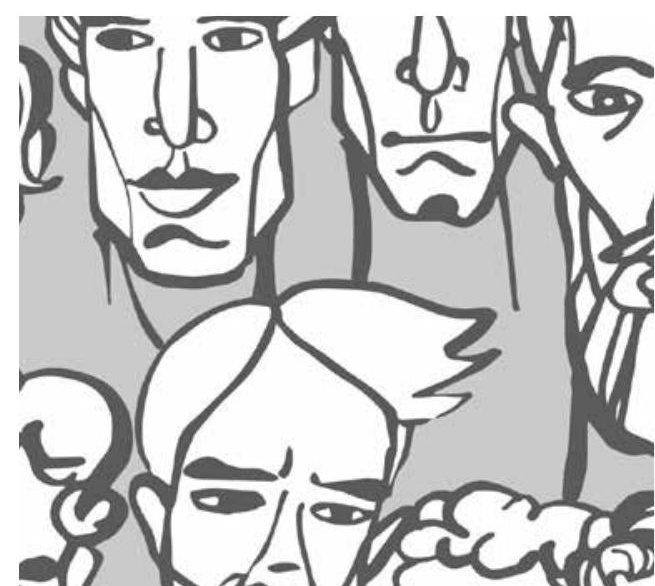




\section{Boletim Técnico do Senac - Instrução aos colaboradores}

1. Os originais enviados serão apreciados pela Comissão e pelos Conselhos Editoriais do Boletim Técnico do Senac: Revista da Educação Profissional, que opinarão sobre a conveniência de sua publicação; em caso de aceitação, o autor receberá um pró-labore. Os direitos de reprodução ("copyright") dos trabalhos aceitos serão de propriedade do Senac. Todos os artigos publicados serão disponibilizados no link: www.senac.br/conhecimento/boletim-tecnico-do-senac.aspx; o diretor da Revista, no entanto, atenderá a qualquer solicitação justa do autor para reprodução do trabalho em outra publicação técnica.

2. Fica entendido que os trabalhos aceitos estarão sujeitos à revisão editorial. Qualquer modificação substancial no texto será submetida ao autor.

3. Os artigos nacionais e internacionais devem ser inéditos e ter no mínimo 10 e no máximo 25 laudas padronizadas (2.100 caracteres por lauda) de elementos textuais (corpo do texto, citações, notas, tabelas, quadros e figuras), conforme NBR 6022 - Artigo em publicação periódica científica impressa - Apresentação.

4. Os artigos internacionais devem ser inéditos e ter no mínimo 10 e no máximo 25 laudas padronizadas (2.100 caracteres com espaços por lauda).

5. O autor deverá adotar as seguintes normas na apresentação de originais:

a) todas as colaborações deverão ser enviadas por e-mail, editadas em Microsoft Word for Windows - versão 6.0 ou superior. O texto deverá obedecer à ortografia oficial, em espaço 1,5 com margens de $3 \mathrm{~cm}$ nos quatro lados do texto e fonte corpo 12 para texto e 10 para citações.

b) o trabalho deve ser acompanhado de palavras-chave, resumo - em português - contendo de 500 a 600 caracteres e folha inicial de identificação, com as seguintes informações: título do trabalho; nome(s) autoral(ais); indicação da instituição principal à qual o autor se vincula, cargo ou função que nela exerce; título e/ou formação acadêmica; endereço, e-mail e telefone para contato;

c) citações diretas breves (transcrições até três linhas) devem constar no próprio texto, entre aspas; as citações diretas longas (transcrições de mais de três linhas) devem constar em parágrafos próprios, sem aspas, com espaço simples de entrelinha, com recuo de $4 \mathrm{~cm}$ e fonte menor que a utilizada no texto;

d) toda e qualquer citação, seja direta (transcrição), seja conceitual (paráfrase), deve ter obrigatoriamente identificação completa da fonte, de acordo com a norma NBR 10520, da Associação Brasileira de Normas Técnicas (ABNT). As citações devem ser indicadas no texto pelo sistema autor-data e a fonte deverá vir no item Referências, ao final do artigo, de acordo com a norma NBR 6023. Nas citações diretas deverá constar o número da página, após a data, no corpo do texto:

e) as notas explicativas deverão ser numeradas consecutivamente, em algarismos arábicos, na ordem em que surgem no texto, e listadas no final do artigo como nota de fim;

f) os gráficos e tabelas devem ser enviados separadamente, com as respectivas legendas, indicando no texto o lugar em que devem inserir-se;

g) destaca-se aos autores a conveniência de: não empregar abreviações, jargões e neologismos desnecessários; apresentar por extenso o significado de qualquer sigla ou braquigrafia na primeira vez em que surge no texto; utilizar títulos concisos, que expressem adequadamente os conteúdos correspondentes.

O autor deve enviar para o e-mail: comunicacao.integracao@senac.br

Boletim Técnico do Senac - A Revista da Educação Profissional

Senac - Departamento Nacional

Av. Ayrton Senna, 5.555 - Bloco D - sala 302 - Barra da Tijuca CEP 22775-004 - Rio de Janeiro/RJ

Tel.: (21) 2136-5622 


\section{O SENAG JÁ TRANSFORMOU A VIDA DE MILLÕES DE BRASILEIROS. E VOGË, EMPRESÁRIO, AJUDOU A ESGREVER ESSA HISTÓRIA.}

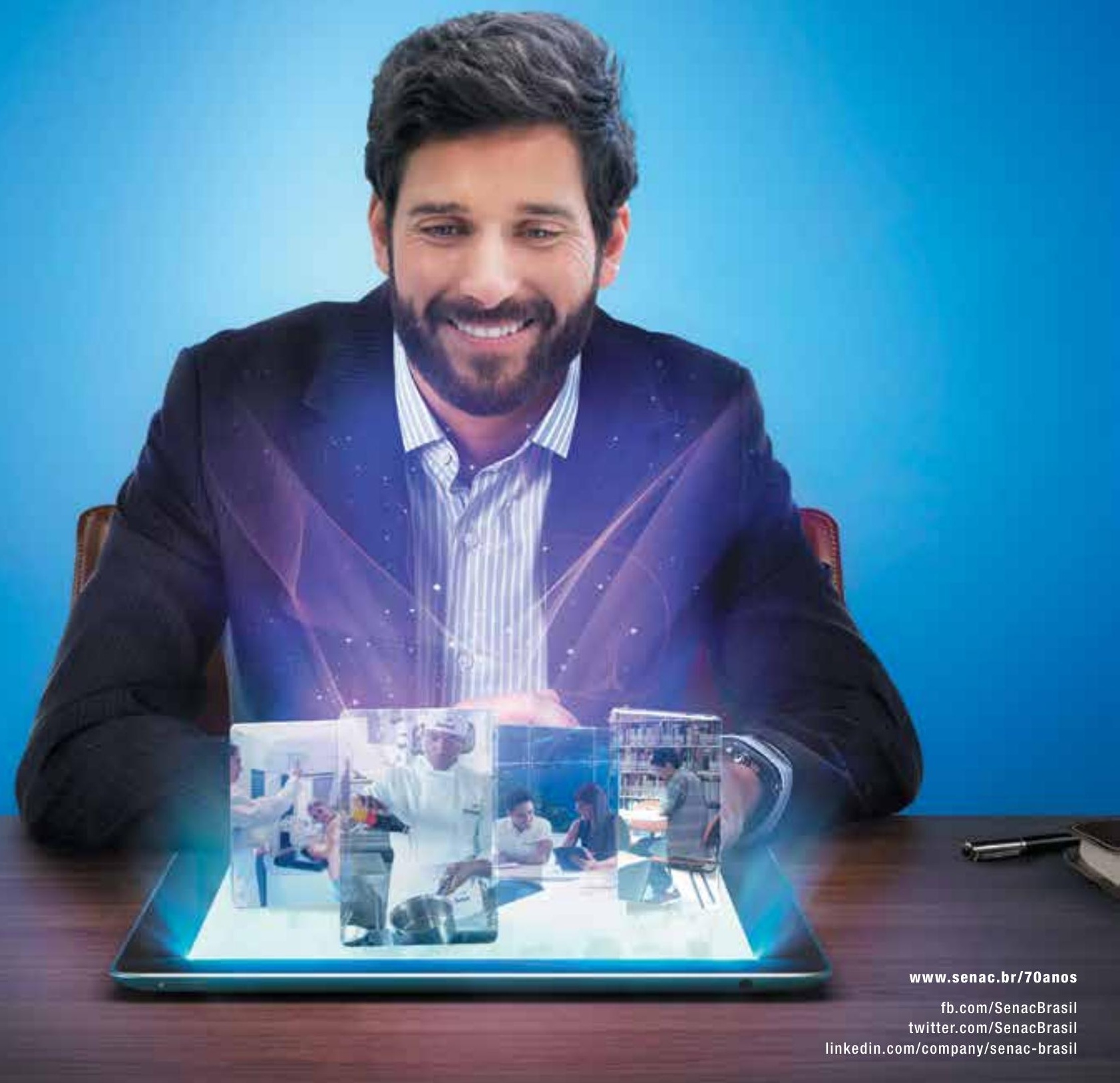

Em 70 anos, 0 mundo não parou de mudar. 0 Senac também não.

Por isso, capacitamos milhões de brasileiros em nossos cursos presenciais e a distância, investimos em infraestrutura, desenvolvemos tecnologia, produzimos conhecimento com a publicação de materiais didáticos e contribuímos para o crescimento de empresas com nossas consultorias. Assim, provocamos verdadeiras transformações de vidas, com reflexo imediato no mercado que recebe profissionais muito mais qualificados e preparados.

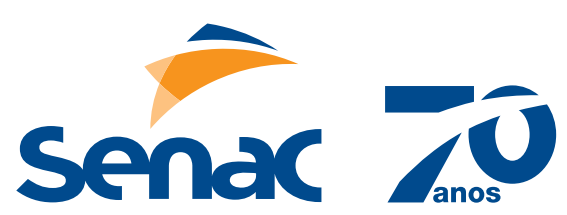



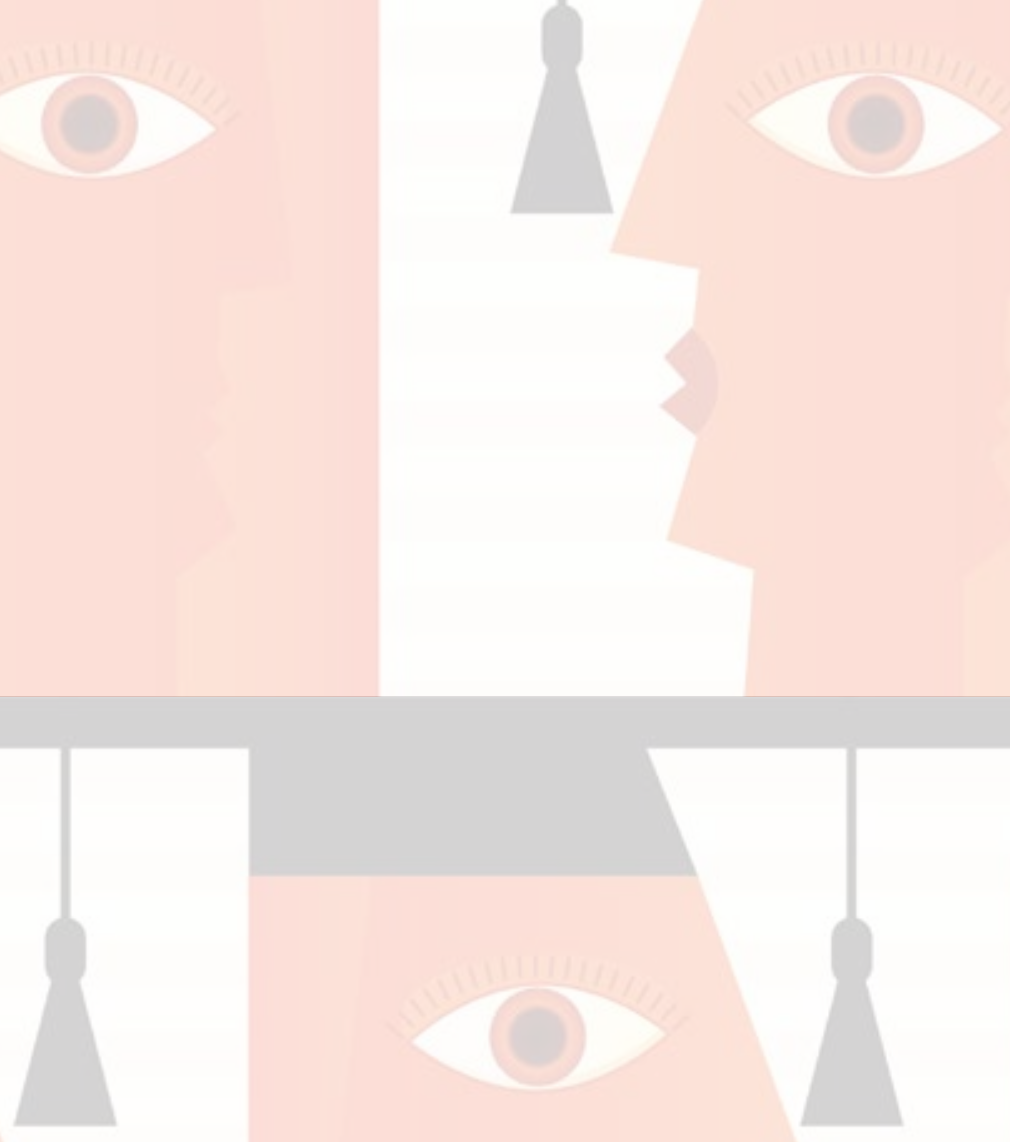

senac 20 